\title{
Application of the survey protocol for chytridiomycosis to Queensland, Australia
}

\author{
Lee F. Skerratt ${ }^{1, *}$, Keith R. McDonald ${ }^{2}$, Harry B. Hines ${ }^{3}$, Lee Berger ${ }^{1}$, Diana Mendez ${ }^{1}$, \\ Andrea D. Phillott ${ }^{1}$, Scott D. Cashins ${ }^{1}$, Kris A. Murray ${ }^{4}$, Richard Speare ${ }^{1}$ \\ ${ }^{1}$ Amphibian Disease Ecology Group, School of Public Health, Tropical Medicine and Rehabilitation Sciences, \\ James Cook University, Townsville, Queensland 4811, Australia \\ ${ }^{2}$ Amphibian Disease Ecology Group, Queensland Parks and Wildlife Service, PO Box 975, Atherton, \\ Queensland 4883, Australia \\ ${ }^{3}$ Queensland Parks and Wildlife Service, PO Box 64, Bellbowrie, Queensland 4070, Australia \\ ${ }^{4}$ The Ecology Centre, School of Biological Sciences, University of Queensland, St Lucia, Queensland 4072, Australia
}

\begin{abstract}
Spread of the amphibian chytrid fungus Batrachochytrium dendrobatidis $(B d)$, which causes chytridiomycosis, has resulted in the extinction of frogs, but the distribution of $B d$ is incompletely known. We trialled the survey protocol for $B d$ by attempting to systematically map its distribution in Queensland, Australia. Bd was easily detected in known infected areas, such as the Wet Tropics and South East Queensland. It was not detected in bioregions adjacent to, but inland from or to the north of, infected regions: Einasleigh Uplands and Cape York adjacent to the infected Wet Tropics; and Brigalow Belt South adjacent to the infected South East Queensland bioregion. These regions where $B d$ was not detected have bordered infected regions for between $15 \mathrm{yr}$ (in northern Queensland) and $30 \mathrm{yr}$ (in southern Queensland), and so they define the geographical limits of $B d$ with regard to the long-term environmental conditions in Queensland. The Gulf Plains, a bioregion distant from infected bioregions, was also negative. $B d$ was confined to rainforest and bordering habitats, such as wet eucalypt forests. Infections were largely confined to permanent water-associated species, consistent with this being an important cause of this group having the greatest declines. Our data supports biogeographic climatic models that show much of inland and northern Australia to be too hot and dry to support $B d$. As there is limited opportunity for $B d$ to spread further in Queensland, the priority for management is reducing the impact of $B d$ in affected populations and assisting frogs to disperse into their former distributions. Given that the survey protocol has been applied successfully in Australia it may be useful for mapping the distribution of $B d$ in other parts of the world.
\end{abstract}

KEY WORDS: Chytridiomycosis $\cdot$ Amphibian $\cdot$ Threatening process $\cdot$ Spread $\cdot$ Management $\cdot$ Disease

\section{INTRODUCTION}

The disease chytridiomycosis, caused by the fungus Batrachochytrium dendrobatidis $(B d)$, probably invaded Australia in the 1970s, resulting in declines and extinctions of susceptible frog species (Berger et al. 1999a, Skerratt et al. 2007). Infection with the amphibian chytrid fungus resulting in chytridiomycosis is a key threatening process for Australian frogs and there is a Threat Abatement Plan (Australian Government
Department of the Environment and Heritage 2006a). However, due to a lack of systematic surveillance, it is not known whether chytridiomycosis is continuing to spread or whether it has reached the limits of its distribution in Australia. This information is important for conservation of amphibians and vital for wildlife managers.

Although a national survey to map the distribution of chytridiomycosis was recommended in the Australian Threat Abatement Plan for infection of frogs with the 
amphibian chytrid fungus (Australian Government Department of the Environment and Heritage 2006a), as yet such a survey has not been completed. The current data on the distribution of $B d$ in Australia is incomplete and has been derived from opportunistic collection of sick or dead frogs (Berger et al. 2004) or surveys of healthy frogs from targeted locations, including examination of archived specimens (Retallick et al. 2004, McDonald et al. 2005, Speare et al. 2005, Obendorf 2005, Obendorf \& Dalton 2006, Kriger \& Hero 2007a, Speare \& Berger 2007, Kriger et al. 2007). Chytridiomycosis has a very broad amphibian host range and is known to occur in eastern Australia from Victoria north to Cooktown, occurring mainly on or between the Great Dividing Range and the coast, in Tasmania, around Adelaide in South Australia, and in southwest Western Australia (Aplin \& Kirkpatrick 2000, Berger et al. 2004, Speare et al. 2005, Obendorf \& Dalton 2006, Murray et al. 2010). Climatic models describing the known distribution show that it is unlikely to occur in hot or dry areas such as the Northern Territory, northwest Western Australia and inland arid areas of Queensland (Retallick 2003). This is supported by laboratory studies showing that heat $\left(\geq 27^{\circ} \mathrm{C}\right)$ and desiccation are detrimental to the fungus (Berger 2001, Johnson et al. 2003, Berger et al. 2004, 2009). A histological survey of 580 frogs from the Ord region in northwest Western Australia was negative, excluding a minimum apparent prevalence of $1 \%$ at a likelihood of 0.95 (Australian Government Department of the Environment and Heritage 2006b).

Skerratt et al. (2008) proposed a standard survey protocol for Australia designed to maximize the likelihood and cost efficiency of detecting $B d$ in frog populations and to enable systematic surveillance and monitoring. The protocol contained 13 guidelines with an additional 5 sub-guidelines (a-e in Step 1) (see below in 'Materials and methods'). Areas were divided into bioregions using the interim biogeographic regionalisation as defined by geology, climate and vegetation for our sampling scale, and to prioritise sampling based on likelihood of a region having $B d$ (see Fig. 1 for Queensland example, Environment Australia 2000, Australian Government Department of the Environment and Water Resources 2007). Species were allocated to groups by the water body they inhabit in order to prioritise sampling based on risk of infection and to extrapolate findings to non-sampled species. The 3 ecological groups were (1) permanent water group - aquatic frogs and those that breed in permanent (lentic or lotic) water bodies (e.g. Litoria wilcoxii, Litoria rheocola, Litoria peronii, Litoria fallax, Limnodynastes peronii, Rheobatrachus spp.), (2) ephemeral water group - frogs that breed in temporary lentic water bodies (e.g. Litoria caerulea, Litoria gracilenta, most Uperoleia spp, Cyclorana spp.) and (3) terrestrial group - frogs that are not associated with water bodies, such as those with intracapsular or direct development (e.g. Assa darlingtoni and the microhylids such as Cophixalus ornatus) (Tyler 1994, Cogger 2000). Some frog species typically breed in both permanent and ephemeral water bodies (e.g. Litoria rubella, Litoria caerulea, Litoria bicolor and Litoria inermis). If sampling these species, then the type of water body that they are associated with should be recorded.

To begin mapping Australia in a systematic way and to trial the protocol, we tested threatened populations in South East Queensland and Wet Tropics bioregions; populations of unknown infection status in the bioregions Einasleigh Uplands, Cape York and Brigalow Belt South, which are adjacent to infected bioregions; ecological groups and species not previously sampled in infected bioregions South East Queensland and Wet Tropics; and the Gulf Plans bioregion, which is distant from infected bioregions.

In the present study, the term anthropogenic spread is used to mean spread of $B d$ through human-associated activities, deliberate or accidental. To date there is no evidence in Queensland that $B d$ has been transmitted by anthropogenic means, apart from the original introduction into South East Queensland, possibly via an infected imported amphibian into the port of Brisbane in the $1970 \mathrm{~s}$, as the first museum record of $B d$ in Australia occurred there in 1979 (Australian Government Department of the Environment and Heritage 2006b). Hygiene protocols recommended in guidelines and enforced through Queensland Parks and Wildlife scientific permits aim to reduce the likelihood of anthropogenic spread (Phillott et al. 2010, this Special).

Evaluating the survey protocol for $B d$ in Skerratt et al. (2008) is important internationally as it is the only published protocol and can be adapted to other countries which are also dealing with this spreading pathogen. Data collected opportunistically prior to implementation of the protocol is included for comparison. The feasibility of the protocol is described in 'Materials and methods'.

\section{MATERIALS AND METHODS}

We followed the survey protocol (Skerratt et al. 2008) to test its feasibility for Queensland. Each frog was captured by hand, with a pair of single-use disposable plastic bags or gloves covering the hands, in order to avoid transferring pathogens between individuals, from 2005 onwards. We followed the hygiene protocol described by Speare et al. (2004). We swabbed the posterior ventral surfaces of the lower abdomen, thighs, 
and all hands and feet of individual frogs twice. Real time TaqMan quantitative PCR (qPCR) was conducted on skin swab samples following the protocol of Boyle et al. (2004). In our laboratory, the sensitivity of this test on individual samples of wild rainforest stream frogs from Queensland is approximately $73 \%$ (L. F. Skerratt et al. unpubl.). The specificity was estimated to be close to $100 \%$ for the procedure used to test samples from 2007 onwards and variable between 94 and 99\% prior to 2007 (L. F. Skerratt et al. unpubl.). DNA was extracted from individual samples, batched into groups of 5 according to the species, date and site of collection, and tested. If a batch tested positive, individual samples from that batch were tested. Each PCR test was run in triplicate with the concentration of $B d$ DNA in zoospore equivalents calculated by Corbett RotorGene software. Where only 1 or 2 wells were positive and the amount of DNA detected was low, the result was considered indeterminate and the sample was retested. The sample was classed as negative if $<3$ wells were positive upon retesting to ensure higher specificity of the test (L. F. Skerratt et al. unpubl.). Histological analyses were conducted on toe-tips and tadpole mouthparts following the methods of Berger et al. (1999b, 2002).

The steps of the survey protocol (Skerratt et al. 2008) are set out below in bold, followed by our approach and comments on the feasibility of fulfilling each section.

(1) Choose bioregions based on priorities of threatened species, regions next to infected regions, ecological groups not sampled and species not sampled in infected bioregions.

(a) Threatened species/populations. (Australian Government Department of the Environment, Water, Heritage and the Arts 2009). Survey protocols employed to date have detected $B d$ in these species and populations, as $B d$ is the threatening process for most (Australian Government Department of the Environment and Heritage 2006a,b). To test the survey protocol on threatened species and populations, we chose the bioregions of subtropical South East Queensland (Main Range National Park) and Wet Tropics (6 locations) where most threatened species have been recorded (see Fig. 1). These are rainforest bioregions known to have frog populations infected with $B d$ and served as positive controls for this survey. The species sampled belonged to the permanent water group and were associated with streams in mesic habitats.

(b) Uninfected bioregions next to infected bioregions. We chose the Einasleigh Uplands (Millstream National Park and adjacent state forests and Silver Valley south of Herberton) and Cape York (McIlwraith Ranges and Endeavour Valley), west and north, respectively, of the infected Wet Tropics. Two of these locations, Millstream National Park and Endeavour
Valley, border the Wet Tropics infected bioregion. The other, McIlwraith Ranges, is considered at risk for chytridiomycosis based on climatic modelling and the presence of the permanent water group, and species within this group such as Litoria eucnemis that occur in streams (Retallick 2003, Puschendorf 2009). The McIlwraith Ranges is, however, located $300 \mathrm{~km}$ from the nearest known infected area. Sampling in this location commenced in 1999 using histology of toe tips with the aim of detecting $B d$ should it arrive, and changed to swabs and qPCR in 2004. We also chose the Brigalow Belt South, northwest of the infected bioregion South East Queensland. We had sampled Brigalow Belt North previously in 2002 using histology, and the results are included here. These adjacent bioregions are generally hot, dry and flat with open forest or woodland, as opposed to the infected ones, which are generally cool, wet and mountainous with rainforest or wet sclerophyll forests. We sampled permanent and ephemeral water group species.

(c) Ecological groups not sampled in infected bioregions. We chose the ephemeral water group within the Wet Tropics and South East Queensland bioregions. We did not choose the terrestrial group, as these had already been or were being extensively sampled in the Wet Tropics.

(d) Species not sampled in infected bioregions. We chose to sample species that belonged to the permanent water group within the infected Wet Tropics bioregion, as other species belonging to this group are infected.

(e) Regions not next to infected regions. This is not a priority unless there is a risk of anthropogenic spread and would not normally be undertaken if regions adjacent to infected regions proved negative; however, we undertook it in order to test the feasibility of the proto$\mathrm{col}$ in these areas.

We chose the Gulf Plains (Normanton) in far northwest Queensland, which is generally hot, dry and flat with woodland. The uninfected bioregions Einasleigh Uplands and Cape York separate the Gulf Plains from the known infected Wet Tropics.

(2) Determine which ecological groups and species are present within the bioregion.

All 3 ecological groups were present in each bioregion chosen, apart from the dry bioregions of Gulf Plains, Einasleigh Uplands and Brigalow Belt South and North, which contained only the permanent and ephemeral water groups.

(3) Determine the distribution of species within the ecological groups present.

Records from the Queensland Museum, published literature and unpublished data of herpetologists were used to determine the species distributions by bioregion. 
(4) Choose species (at least 2) which represent the ecological group to be sampled throughout the distribution of the ecological group within the bioregion (choose species that are easy to find, widely distributed and are likely to be infected with $B d$ ).

We applied this step in the protocol to groups not previously surveyed in both infected and uninfected bioregions. For the Einasleigh Uplands, we chose Litoria caerulea and L. rubella to represent the ephemeral water group. For the Gulf Plains, we chose Cyclorana novaehollandiae and $L$. pallida to represent the ephemeral water group. We also chose L. caerulea and L. latopalmata for the Brigalow Belt South and South East Queensland to represent permanent and ephemeral water groups. These choices were made before any field work was attempted. Subsequently, we found that it was difficult to find significant numbers of these targeted species at selected sites when the field work was conducted. The detectability of ephemeral breeders was particularly difficult to predict, and depended on when rainfall occurred locally. Often non-targeted species from the same ecological guilds were more easily detected; for example C. alboguttata was found when looking for L. caerulea.

(5) Select time of year to sample those species, based on maximising the likelihood of detecting both frogs and $B d$. May have to wait for rain for ephemeral water species.

We surveyed the permanent water group throughout the year in the mesic Wet Tropics to investigate the epidemiology of $B d$ as part of another study. For the remaining frog populations we surveyed at times when frogs were most readily found. This included spring in the upland rainforests of Cape York and in the monsoonal summer in the Gulf Plains, Einasleigh Uplands and Brigalow Belt South and North. We surveyed permanent water breeders in spring and summer in South East Queensland. This did not always coincide with optimal ambient temperatures for $B d$ but was necessary in order to capture enough frogs for our required sample size.

(6) Determine accessibility to the distribution of those species within the bioregion.

Accessibility was determined by ease of vehicle and walking access within frog distributions. Prevailing climatic conditions also affected access, with flooded areas in the Gulf Plains and Cape York being inaccessible during the monsoon.

(7) Sample systematically throughout accessible parts of the distribution for each species to be sampled within the bioregion. May need to divide distribution of species within bioregion up into smaller areas if the bioregion is large and prioritise sampling of areas based on likelihood of being infected with Bd. Recommended minimum area within a bioregion to be surveyed is $20 \%$ of accessible distribution of targeted species. Accessible areas may vary throughout the year, for example access is lower in the peak of the monsoonal wet when species are active compared with the early and late monsoon.

It was not necessary to sample threatened species systematically throughout their distribution, as these species have already been identified as infected with $B d$ throughout their distribution. Instead, a few known infected populations were sampled: Mixophyes fleayi at Main Range National Park in the bioregion South East Queensland and populations of Litoria rheocola, L. nannotis, L. genimaculata and Nyctimystes dayi at Tully Gorge, Nandroya Falls, Dinner Falls, Breeden Creek, Big Tableland and Mt. Misery in the Wet Tropics bioregion. These known infected populations for $B d$ served as positive controls for this survey. These species were oversampled in order to examine the sensitivity and specificity of histology and qPCR diagnostic tests and to better understand the epidemiology of chytridiomycosis as part of another study. Transects were walked to keep searching effort constant among species and over time.

For uninfected bioregions adjacent to infected bioregions, we chose small areas most likely to be infected based on proximity to infected areas, such as Millstream Falls National Park and adjacent state forests in the Einasleigh Uplands and Endeavour Valley in Cape York, favourable climate for $B d$ and presence of species most at risk of infection, such as the Mcllwraith Range in Cape York. For regions not next to infected bioregions, such as the Gulf Plains, we tried to sample as systematically and widely as possible throughout the distributions of targeted ecological groups. However, this was impossible logistically due to road closures during the monsoon.

(8) Initially sample groups likely to be infected such as permanent water species followed by ephemeral water species if present.

Published data was examined to determine species likely to be infected with $B d$ (Berger et al. 2004, Speare \& Berger 2007).

(9) Collect samples from at least 60 individual frogs from each species to be sampled. More frogs will need to be sampled from parts of the distribution where they are more abundant so that sampling fractions are consistent and the sample is representative of the population.

It was not always possible to sample this number of frogs because it was too dry at the time of sampling, and species were not easily detected in sufficient numbers or flooding made access impossible. Often, several species needed to be sampled from an ecological group and combined to meet the required sample size. This was a modification of the original protocol. 
(10) Sample the mouthparts of 60 tadpoles for each species concurrently when sampling frogs, if possible, if the likelihood of infection of tadpoles is unknown. Alternatively, if likelihood of infection of tadpoles is known then they may be sampled instead of frogs if they are more convenient to sample and their infection status can be extrapolated to adults.

It was not always possible to sample this number of tadpoles, especially for the ephemeral water group. For instance, at the time of sampling on the Gulf Plains very few tadpoles were detected because breeding had not peaked or the early breeding had resulted in rapid metamorphosis of tadpoles. Tadpoles were easily collected for the permanent water group in the Wet Tropics.

(11) Take a GPS reading at each collection point. A collection point is defined by a $1 \mathrm{~km}$ radius and a maximum of 15 individuals to be collected from each collection point. Space collection points evenly throughout the area to be surveyed for target species.

This was intermittently achieved due to the variable detectability of frogs. Sometimes 20 individuals were sampled from a collection point to ensure an adequate sample size for the population. This was a modification of the original protocol.

Not all collection points are reported here as they were combined for each location to simplify the data set, but all are available from the authors.

(12) Combine sampling of species from different ecological groups where possible.

This was achieved where ecological groups occurred in the same area such as the Wet Tropics.

(13) Test the 60 samples until at least one positive is found, given perfect specificity, or alternatively test the number of samples until one more than the threshold number of positives is detected, given an imperfect specificity. Use software such as Freecalc (AusVet, Brisbane) to calculate the number of samples and threshold number of positives needed. The remaining samples may be tested if additional information on the distribution of $B d$ within a bioregion is needed.

This was possible. For this initial study, we tested all samples collected in order to gain additional information on chytridiomycosis in frog populations. The targeted sampling strategy described in this protocol relies on the assumption that chytridiomycosis spreads throughout the population in the bioregion and that disease clustering does not occur in terms of presence/absence of the disease at the scale of sampling (Skerratt et al. 2008). This is a reasonable assumption, given that chytridiomycosis has spread readily and widely on several continents and has eliminated entire populations and species (Skerratt et al. 2007). This means that results arising from systematic sampling of parts of the distribution of a population can be extrapolated to the remainder of the population. Disease clustering is likely to occur when disease spread does not readily occur, such as among isolated water bodies or where risk factors for disease vary greatly and geographically in their severity. It will also occur when chytridiomycosis first invades a population. Sampling throughout the distribution of the species and 2-stage sampling will be needed to overcome disease clustering, and methods exist for calculating sample sizes which incorporate disease clustering, sampling strategy and uncertainty of test accuracy (Branscum et al. 2006, Joly et al. 2009). Larger sample sizes will be needed if disease clustering occurs to achieve the same level of confidence in disease freedom. The sample size of 60 in this protocol is based on a minimum apparent prevalence of $5 \%$ and a diagnostic test sensitivity and specificity of 73 and $100 \%$, respectively (see Skerratt et al. 2008 for a discussion of sample size calculations for imperfect tests).

In addition to trialling the survey protocol, where available, we report opportunistic results collected prior to development of the protocol at the end of each section of results to allow some comparisons. These results were obtained using histological diagnosis, as the qPCR test had not yet been developed. These results were mostly collected from species in the ephemeral and permanent water groups in the Cape York, Brigalow Belt North, Gulf Plains and Wet Tropics bioregions. Gloves or plastic bags were not generally used prior to 2005 and hands were washed in the water body that frogs inhabited between individual captures. In our laboratory, the sensitivity of histology on individual samples of wild rainforest stream frogs from Queensland is approximately $27 \%$ and the specificity is $100 \%$ (L. F. Skerratt et al. unpubl.).

\section{RESULTS}

\section{Testing priority categories}

Threatened species (1a). The survey of stream breeding species previously known to be infected with $B d$ in the Wet Tropics showed that all 4 species surveyed (Litoria genimaculata, L. nannotis, L. rheocola and Nyctimystes dayi) tested positive for $B d$ by both histology on toe clips and qPCR (Table 1). Prevalence of $B d$ also differed by site, season and species. In South East Queensland, 5\% Mixophyes fleayi (2/39) were positive in summer and in the Wet Tropics, 32\% L. genimaculata (84/267), $25 \%$ L. nannotis (18/71), $36 \%$ L. rheocola (164/452), and $16 \%$ N. dayi (14/88) collected throughout the year were positive. Intensities of infection as measured by zoospore equivalents were 
Table 1. Batrachochytrium dendrobatidis. Presence in frog species at collection points (as defined by Skerratt et al. 2008, these were grouped when $<20 \mathrm{~km}$ from each other and sample size was small, i.e. $<20$ individuals) within bioregions in Queensland. Infection intensity (mean \pm SE, zoospore equivalents) was calculated only when quantitative (qPCR) was used for diagnosis. Histology was used in the Wet Tropics and South East Queensland for comparison with PCR and prior to the introduction of PCR in 2005. The target sample size was up to 20 individuals per species per collection point with at least 60 individuals per species per bioregion collected. Sometimes species had to be combined to achieve the target sample size. All samples, except for those from Gap Creek West and Wet Tropics, were analysed in batches of 5 by qPCR. Where samples could not be equally divided into batches of 5, the remainder were analysed individually. All samples from the Wet Tropics were analysed individually. Samples from Gap Creek West were initially batched, but were re-analysed individually when all batches presented negative for the presence of chytrid. As this location is a known chytrid infection area, samples were re-tested to determine the sensitivity of batching. When retested, two samples presented a very low positive for the presence of $B d$. As all samples were tested in triplicate, those with only 1 to 2 positive wells were regarded as indeterminate; they were then retested and classed as negative if $<3$ wells were positive to ensure a higher specificity of the test. A coordinate for one of the collection points within the area sampled is given when the sample size was $>10$. Priority refers to Step 1 of survey protocol by Skerratt et al. (2008), as detailed in 'Materials and methods'. N: number of frogs

\begin{tabular}{|c|c|c|c|c|c|c|c|c|}
\hline $\begin{array}{l}\text { Priority } \\
\text { Bioregion }\end{array}$ & $\begin{array}{l}\text { Collection } \\
\text { point }\end{array}$ & Habitat & $\begin{array}{l}\text { Water } \\
\text { group }\end{array}$ & Species & Date & $\begin{array}{l}\text { Percent } \\
\text { positive }\end{array}$ & $\begin{array}{l}\text { Mean }( \pm \mathrm{SE}) \\
\text { intensity }\end{array}$ & $\mathrm{N}$ \\
\hline \multicolumn{9}{|c|}{ (a) Threatened species } \\
\hline \multirow[t]{35}{*}{ Wet Tropics } & Breeden Creek & \multirow{7}{*}{ Rainforest } & \multirow{7}{*}{ Permanent } & \multirow{3}{*}{ Litoria genimaculata } & \multirow{3}{*}{ Jun 04-Jun 05} & & & \\
\hline & \multirow[t]{6}{*}{$17^{\circ} 25^{\prime} 32^{\prime \prime} \mathrm{S}, 145^{\circ} 42^{\prime} 11^{\prime \prime} \mathrm{E}$} & & & & & 41 & $152 \pm 111$ & 17 \\
\hline & & & & & & 6 & Histology & 15 \\
\hline & & & & \multirow[t]{2}{*}{ L. nannotis } & \multirow[t]{2}{*}{ Jun 04-Jun 05} & 14 & $101 \pm 100$ & 22 \\
\hline & & & & & & 0 & Histology & 12 \\
\hline & & & & \multirow[t]{2}{*}{ L. rheocola } & \multirow[t]{2}{*}{ Apr 05} & 0 & 0 & 3 \\
\hline & & & & & & 0 & Histology & 3 \\
\hline & \multicolumn{8}{|l|}{ Dinner Falls } \\
\hline & \multirow{2}{*}{$17^{\circ} 25^{\prime} 34^{\prime \prime} \mathrm{S}, 145^{\circ} 29^{\prime} 22^{\prime \prime} \mathrm{E}$} & \multirow[t]{2}{*}{ Rainforest } & \multirow[t]{2}{*}{ Permanent } & \multirow[t]{2}{*}{ L. genimaculata } & \multirow[t]{2}{*}{ Jun 04-Jun 05} & 17 & $25 \pm 5$ & 12 \\
\hline & & & & & & 0 & Histology & 8 \\
\hline & \multirow{5}{*}{$\begin{array}{l}\text { Mt. Misery } \\
15^{\circ} 53^{\prime} 23^{\prime \prime} \mathrm{S}, 145^{\circ} 12^{\prime} 36^{\prime \prime} \mathrm{E}\end{array}$} & \multirow{5}{*}{ Rainforest } & \multirow{5}{*}{ Permanent } & \multirow{3}{*}{ L. genimaculata } & & & & \\
\hline & & & & & Jun 04-Jun 05 & 33 & $3051 \pm 2953$ & 27 \\
\hline & & & & & & 4 & Histology & 26 \\
\hline & & & & L. rheocola & Jun 04-Jun 05 & 37 & $1844 \pm 994$ & 263 \\
\hline & & & & & & 18 & Histology & 180 \\
\hline & Nandroya Creek & & & & & & & \\
\hline & $17^{\circ} 35^{\prime} 50^{\prime \prime} \mathrm{S}, 145^{\circ} 45^{\prime} 27^{\prime \prime} \mathrm{E}$ & Rainforest & Permanent & L. genimaculata & Jun 04-Jun 05 & 0 & 0 & 5 \\
\hline & & & & & & 25 & Histology & 4 \\
\hline & & & & L. nannotis & Dec 04-Jun 05 & 0 & 0 & 8 \\
\hline & & & & & & 17 & Histology & 6 \\
\hline & & & & L. rheocola & Jun 04-Jun 05 & 36 & $121 \pm 83$ & 14 \\
\hline & & & & & & 23 & Histology & 13 \\
\hline & O'Keefes Crossing & & & & & & & \\
\hline & $15^{\circ} 42^{\prime} 29^{\prime \prime} \mathrm{S}, 145^{\circ} 15^{\prime} 49^{\prime \prime} \mathrm{E}$ & Rainforest & Permanent & L. genimaculata & Jun 04-Jun 05 & $\begin{array}{c}31 \\
5\end{array}$ & $\begin{array}{c}193 \pm 56 \\
\text { Histology }\end{array}$ & $\begin{array}{c}176 \\
86\end{array}$ \\
\hline & & & & L. rheocola & Jun 04-Jun 05 & 36 & $285 \pm 152$ & 130 \\
\hline & & & & & & 10 & Histology & 89 \\
\hline & Tully Gorge & & & & & & & \\
\hline & $17^{\circ} 46^{\prime} 19^{\prime \prime} \mathrm{S}, 145^{\circ} 38^{\prime} 45^{\prime \prime} \mathrm{E}$ & Rainforest & Permanent & L. genimaculata & Jun 04-Jun 05 & 40 & $367 \pm 197$ & 30 \\
\hline & & & & & & 0 & Histology & 20 \\
\hline & & & & L. nannotis & Jun 04-Jun 05 & 38 & $367 \pm 247$ & 40 \\
\hline & & & & & & 0 & Histology & 15 \\
\hline & & & & L. rheocola & Jun 04-Jun 05 & 36 & $115 \pm 60$ & 42 \\
\hline & & & & & & 9 & Histology & 32 \\
\hline & & & & Nyctimystes dayi & Jun 04-Jun 05 & 16 & $4242 \pm 3621$ & 88 \\
\hline & & & & & & 3 & Histology & 62 \\
\hline South East & Main Range National Park & Rainforest & Permanent & Mixophyes fleayi & Jan 05 & 5 & 1 & 38 \\
\hline Queensland & $28^{\circ} 02^{\prime} 57^{\prime \prime} \mathrm{S}, 152^{\circ} 23^{\prime} 00^{\prime \prime} \mathrm{E}$ & & & & & 0 & Histology & 38 \\
\hline (b) Bioregion & lext to infected ones & & & & & & & \\
\hline Cape York & McIlwraith Ranges & Rainforest & Permanent & L. eucnemis & Sep 93-Sep 02 & 0 & Histology & 181 \\
\hline & $13^{\circ} 44^{\prime} 4^{\prime \prime} \mathrm{S}, 143^{\circ} 20^{\prime} 23^{\prime \prime} \mathrm{E}$ & & & & Sep 04 & 0 & 0 & 94 \\
\hline & & & & L. longirostris & Aug 99-Sep 02 & 0 & Histology & 111 \\
\hline & & & & & Sep 04 & 0 & 0 & 214 \\
\hline & & & & Rana daemeli & Aug 02-Sep 02 & 0 & Histology & 61 \\
\hline & Endeavour Valley & Dry eucalypt & Permanent & L. lesueuri & Sep 05-Sep 06 & 0 & 0 & 34 \\
\hline & $15^{\circ} 25^{\prime} 44^{\prime \prime} \mathrm{S}, 145^{\circ} 7^{\prime} 12^{\prime \prime} \mathrm{E}$ & & Ephemeral & L. inermis & Jan 05-Sep 06 & 0 & 0 & 13 \\
\hline & & & & Uperoleia mimula & Mar 06 & 0 & 0 & 5 \\
\hline
\end{tabular}


Table 1 (continued)

\begin{tabular}{|c|c|c|c|c|c|c|c|c|}
\hline $\begin{array}{l}\text { Priority } \\
\text { Bioregion }\end{array}$ & $\begin{array}{l}\text { Collection } \\
\text { point }\end{array}$ & Habitat & $\begin{array}{l}\text { Water } \\
\text { group }\end{array}$ & Species & Date & $\begin{array}{l}\text { Percent } \\
\text { positive }\end{array}$ & $\begin{array}{l}\text { Mean }( \pm \text { SE }) \\
\text { intensity }\end{array}$ & $\mathrm{N}$ \\
\hline & & & & L. microbelos & Mar 03 & 0 & Histology & 6 \\
\hline & & & & L. nigrofrenata & Mar 03 & 0 & Histology & 5 \\
\hline & & & & L. bicolor & Mar 03 & 0 & Histology & 5 \\
\hline & & & & & Mar 03 & 0 & Histology & 12 \\
\hline & & & & Others & Jan 05-Mar 06 & 0 & 0 & 10 \\
\hline & Cape Melville National Park & Vine forest & Permanent & L. andiirrmalin & Nov 01 & 0 & Histology & 9 \\
\hline & $14^{\circ} 15^{\prime} 24^{\prime \prime} \mathrm{S}, 144^{\circ} 27^{\prime} 40^{\prime \prime} \mathrm{E}$ & Dry eucalypt & Ephemeral & Others & Feb 02 & 0 & Histology & 8 \\
\hline \multirow{8}{*}{$\begin{array}{l}\text { Einasleigh } \\
\text { Uplands }\end{array}$} & Ravenshoe State Forest & Wet eucalypt & Semi- & L. fallax & Mar 06 & 0 & 0 & 21 \\
\hline & $17^{\circ} 35^{\prime} 56^{\prime \prime} \mathrm{S}, 145^{\circ} 27^{\prime} 45^{\prime \prime} \mathrm{E}$ & & Permanent & U. altissima & Mar 06 & 0 & 0 & 21 \\
\hline & & & & L. rubella & Mar 06 & 0 & 0 & 2 \\
\hline & Silver Valley & Dry eucalypt & Ephemeral & L. lesueuri & Sep 06 & 0 & 0 & 6 \\
\hline & Millstream National Park & Dry eucalypt & Ephemeral & L. gracilenta & Jan 05-Mar 06 & 0 & 0 & 65 \\
\hline & $17^{\circ} 38^{\prime} 37^{\prime \prime} \mathrm{S}, 145^{\circ} 27^{\prime} 30^{\prime \prime} \mathrm{E}$ & & & L. rubella & Jan 05-Mar 06 & 0 & 0 & 20 \\
\hline & & & & Others & Jan 05-Mar 06 & 0 & 0 & 5 \\
\hline & Glen Gordon Station & Dry eucalypt & Ephemeral & Others & Feb 02 & 0 & Histology & 7 \\
\hline Brigalow Belt & Kurumbul & Dry eucalypt & Ephemeral & Cyclorana alboguttata & Jan-Mar 05 & 0 & 0 & 50 \\
\hline South & $28^{\circ} 34^{\prime} 28^{\prime \prime} \mathrm{S}, 150^{\circ} 34^{\prime} 21^{\prime \prime} \mathrm{E}$ & & & L. latopalmata & Jan 05 & 0 & 0 & 15 \\
\hline Brigalow Belt & Bowen & Dry eucalypt & Ephemeral & C. alboguttata & Feb 02 & 0 & Histology & 7 \\
\hline \multirow[t]{4}{*}{ North } & $19^{\circ} 56^{\prime} 59^{\prime \prime} \mathrm{S}, 148^{\circ} 6^{\prime} 17^{\prime \prime} \mathrm{E}$ & & & L. nasuta & Feb 02 & 0 & Histology & 5 \\
\hline & & & & Others & Feb 02 & 0 & Histology & 18 \\
\hline & $\begin{array}{l}\text { Bowen to Collinsville Road } \\
20^{\circ} 4^{\prime} 19^{\prime \prime} \mathrm{S}, 148^{\circ} 9^{\prime} 7^{\prime \prime} \mathrm{E}\end{array}$ & Dry eucalypt & Ephemeral & Others & Feb 02 & 0 & Histology & 19 \\
\hline & $\begin{array}{l}\text { Strathalbyn Road } \\
20^{\circ} 18^{\prime} 21^{\prime \prime} \mathrm{S}, 147^{\circ} 51^{\prime} 57^{\prime \prime} \mathrm{E}\end{array}$ & Dry eucalypt & Ephemeral & Others & Feb 02 & 0 & Histology & 19 \\
\hline \multicolumn{9}{|c|}{ (c) Ecological groups not surveyed in infected bioregions } \\
\hline \multirow[t]{19}{*}{ Wet Tropics } & $\begin{array}{l}\text { Robson Creek } \\
17^{\circ} 7^{\prime} 45^{\prime \prime} \mathrm{S}, 145^{\circ} 37^{\prime} 34^{\prime \prime} \mathrm{E}\end{array}$ & Rainforest & Ephemeral & L. xanthomera & Feb 07 & 0 & 0 & 21 \\
\hline & $\begin{array}{l}\text { Mt Baldy State Forest } \\
17^{\circ} 19^{\prime} 58^{\prime \prime} \mathrm{S}, 145^{\circ} 25^{\prime} 3^{\prime \prime} \mathrm{E}\end{array}$ & Rainforest & Ephemeral & L. xanthomera & Feb 07 & 16 & $427 \pm 239$ & 19 \\
\hline & Millaa Millaa & Rainforest & Ephemeral & L. xanthomera & Feb 07 & 0 & 0 & 23 \\
\hline & $\begin{array}{l}\text { Environmental Park } \\
17^{\circ} 29^{\prime} 52^{\prime \prime} \mathrm{S}, 145^{\circ} 36^{\prime} 46^{\prime \prime} \mathrm{E}\end{array}$ & & & & & & & \\
\hline & $\begin{array}{l}\text { Cattle Camp Quarry } \\
17^{\circ} 19^{\prime} 45^{\prime \prime} \mathrm{S}, 145^{\circ} 27^{\prime} 0 " \mathrm{E}\end{array}$ & Wet eucalypt & Ephemeral & L. gracilenta & Jan 07 & 0 & 0 & 12 \\
\hline & & & & L. rubella & Jan 07 & 0 & 0 & 20 \\
\hline & & & & U. altissima & Jan 07 & 0 & 0 & 20 \\
\hline & & & & Others & Jan 07 & 0 & 0 & 7 \\
\hline & $\begin{array}{l}\text { Webster Road } \\
17^{\circ} 26^{\prime} 16^{\prime \prime} \mathrm{S}, 145^{\circ} 27^{\prime} 25^{\prime \prime} \mathrm{E}\end{array}$ & $\begin{array}{l}\text { Wet eucalypt/ } \\
\text { near rainforest }\end{array}$ & Ephemeral & L. xanthomera & Jan-Feb 07 & 15 & $19 \pm 10$ & 20 \\
\hline & & & & Others & Jan 07 & 0 & 0 & 8 \\
\hline & $\begin{array}{l}\text { Tumoulin } \\
17^{\circ} 32^{\prime} 24^{\prime \prime} \mathrm{S}, 145^{\circ} 27^{\prime} 0^{\prime \prime} \mathrm{E}\end{array}$ & Wet eucalypt & Ephemeral & Others & Jan 05 & 0 & 0 & 10 \\
\hline & $\begin{array}{l}\text { Tully valley } \\
17^{\circ} 50^{\prime} 22^{\prime \prime} \mathrm{S}, 145^{\circ} 42^{\prime} 57^{\prime \prime} \mathrm{E}\end{array}$ & $\begin{array}{l}\text { Banana } \\
\text { plantations }\end{array}$ & Ephemeral & L. infrafrenata & Oct $00-$ Aug 02 & 0.3 & Histology & 295 \\
\hline & & & & L. gracilenta & Oct $00-$ Aug 02 & 0 & Histology & 242 \\
\hline & & & & L. fallax & Oct $00-$ Aug 02 & 0 & Histology & 85 \\
\hline & & & & L. rubella & Oct $00-$ Jan 02 & 0 & Histology & 24 \\
\hline & & & & L. rothii & Oct $00-$ Mar 02 & 0 & Histology & 19 \\
\hline & & & & L. caerulea & Nov 00-Jun 02 & 0 & Histology & 12 \\
\hline & $\begin{array}{l}\text { Kuranda } \\
16^{\circ} 55^{\prime} 17^{\prime \prime} \mathrm{S}, 145^{\circ} 34^{\prime} 55^{\prime \prime} \mathrm{E}\end{array}$ & Wet eucalypt & Ephemeral & Others & Feb 03 & 0 & Histology & 25 \\
\hline & $\begin{array}{l}\text { Mt. Hypipamee } \\
\text { National Park }\end{array}$ & Rainforest & Terrestrial & $\begin{array}{c}\text { Austrochaperina } \\
\text { robusta }\end{array}$ & Oct 01 & 0 & Histology & 6 \\
\hline \multirow{6}{*}{$\begin{array}{l}\text { South East } \\
\text { Queensland }\end{array}$} & Haigslea & Dry eucalypt & Ephemeral & L. caerulea & Jan 05 & 0 & 0 & 11 \\
\hline & $27^{\circ} 34^{\prime} 15^{\prime \prime} \mathrm{S}, 152^{\circ} 37^{\prime} 48^{\prime \prime} \mathrm{E}$ & & & & & 0 & Histology & 10 \\
\hline & Pine Mountain & Dry eucalypt & Ephemeral & L. caerulea & Jan 05 & 0 & 0 & 11 \\
\hline & $27^{\circ} 32^{\prime} 38^{\prime \prime} \mathrm{S}, 152^{\circ} 42^{\prime} 42^{\prime \prime} \mathrm{E}$ & & & & & 0 & Histology & 10 \\
\hline & Moggill & Dry eucalypt & Ephemeral & L. caerulea & Jan 05 & 0 & 0 & 19 \\
\hline & $27^{\circ} 35^{\prime} 42^{\prime \prime} \mathrm{S}, 152^{\circ} 51^{\prime} 27^{\prime \prime} \mathrm{E}$ & & & & & 0 & Histology & 19 \\
\hline
\end{tabular}


Table 1 (continued)

\begin{tabular}{|c|c|c|c|c|c|c|c|c|}
\hline $\begin{array}{l}\text { Priority } \\
\text { Bioregion }\end{array}$ & $\begin{array}{l}\text { Collection } \\
\text { points }\end{array}$ & Habitat & $\begin{array}{l}\text { Water } \\
\text { group }\end{array}$ & Species & Date & $\begin{array}{l}\text { Percent } \\
\text { positive }\end{array}$ & $\begin{array}{l}\text { Mean }( \pm \mathrm{SE}) \\
\text { intensity }\end{array}$ & $\mathrm{N}$ \\
\hline $\begin{array}{l}\text { Central } \\
\text { Mackay Coast }\end{array}$ & $\begin{array}{l}\text { Dingo Beach Road } \\
20^{\circ} 6^{\prime} 22^{\prime \prime} \mathrm{S}, 148^{\circ} 29^{\prime} 29^{\prime \prime} \mathrm{E}\end{array}$ & Dry eucalypt & Ephemeral & Others & Feb 02 & 0 & Histology & 11 \\
\hline \multicolumn{9}{|c|}{ (d) Species not surveyed in infected bioregions } \\
\hline \multirow[t]{5}{*}{ Wet Tropics } & Breeden Creek & Rainforest & Permanent & L. lesueuri & Oct 04 & $\begin{array}{c}100 \\
40\end{array}$ & $\begin{array}{c}13231 \pm 12761 \\
\text { Histology }\end{array}$ & $\begin{array}{l}5 \\
5\end{array}$ \\
\hline & Mt. Misery & Rainforest & Permanent & L. lesueuri & Oct 04 & $\begin{array}{c}33 \\
0\end{array}$ & $\begin{array}{c}1 \\
\text { Histology }\end{array}$ & $\begin{array}{l}3 \\
3\end{array}$ \\
\hline & O'Keefes Crossing & Rainforest & Permanent & L. lesueuri & Oct-Dec 04 & $\begin{array}{c}25 \\
0\end{array}$ & $\begin{array}{c}2 \\
\text { Histology }\end{array}$ & $\begin{array}{l}4 \\
2\end{array}$ \\
\hline & Tully Valley & Rainforest & Permanent & L. lesueuri & Oct 04 & 0 & 0 & 7 \\
\hline & Webster Road & Wet eucalypt & Permanent & L. lesueuri & Jan 07 & 0 & 0 & 20 \\
\hline \multicolumn{9}{|c|}{ (e) Bioregions not next to infected ones } \\
\hline \multirow[t]{6}{*}{ Gulf Plains } & $\begin{array}{l}\text { Normanton } \\
17^{\circ} 43^{\prime} 23^{\prime \prime} \mathrm{S}, 141^{\circ} 0^{\prime} 0^{\prime \prime} \mathrm{E}\end{array}$ & Dry eucalypt & Ephemeral & C. novaehollandiae & Jan 05 & 0 & 0 & 54 \\
\hline & & & & L. caerulea & Jan 05 & 0 & 0 & 8 \\
\hline & & & & Others & Jan 05 & 0 & 0 & 9 \\
\hline & $\begin{array}{l}\text { Burke and Wills Roadhouse } \\
17^{\circ} 17^{\prime} 3^{\prime \prime} \mathrm{S}, 140^{\circ} 27^{\prime} 36^{\prime \prime} \mathrm{E}\end{array}$ & Dry eucalypt & Ephemeral & C. australis & Mar 03 & 0 & Histology & 18 \\
\hline & & & & C. brevipes & Mar 03 & 0 & Histology & 6 \\
\hline & & & & Others & Mar 03 & 0 & Histology & 10 \\
\hline
\end{tabular}

highly variable (Table 1). The batches of samples of $M$. fleayi were initially negative but 2 individual samples in separate batches were positive upon retesting. As this location is a known chytrid infection area, samples were re-tested to determine the sensitivity of batching. Both these samples were at the limit of detection for the qPCR at 1 zoospore equivalent (Table 1). Prevalence of $B d$ increased with lower temperatures in the
Wet Tropics during the cooler months for adults of $L$. nannotis, L. rheocola and $N$. dayi and tadpoles of $L$. nannotis (Table 2). Abundance of frog species differed by site and season.

Bioregions not surveyed next to infected bioregions (1b). In these surveys, we targeted the groups most likely to be infected, such as the permanent water group and then the ephemeral water

Table 2. Batrachochytrium dendrobatidis. Comparison of mean percentage prevalence in tadpoles and adults in frog species in the Wet Tropics in 2006-2007 followed by a Bayesian shortest confidence interval in brackets. (-) No specimens tested

\begin{tabular}{|c|c|c|c|c|c|c|c|c|}
\hline \multirow[t]{4}{*}{ Species } & \multicolumn{8}{|c|}{ Prevalence (\%) } \\
\hline & \multirow{2}{*}{\multicolumn{2}{|c|}{ Tully Winter }} & \multirow{2}{*}{\multicolumn{2}{|c|}{ Kirrama }} & \multirow{2}{*}{\multicolumn{2}{|c|}{${ }_{\text {Tully }}$ Summ }} & \multirow{2}{*}{\multicolumn{2}{|c|}{ Kirrama }} \\
\hline & & & & & & & & \\
\hline & Tadpole & Adult & Tadpole & Adult & Tadpole & Adult & Tadpole & Adult \\
\hline Litoria genimaculata $^{\mathrm{a}}$ & $\begin{array}{c}4 \\
(1-11)\end{array}$ & $\begin{array}{c}100 \\
(22-100)\end{array}$ & $\begin{array}{c}5 \\
(1-14)\end{array}$ & $\begin{array}{c}34 \\
(20-51)\end{array}$ & $\begin{array}{c}17 \\
(6-34)\end{array}$ & - & $\begin{array}{c}6 \\
(2-12)\end{array}$ & $\begin{array}{c}10 \\
(1-37)\end{array}$ \\
\hline L. nannotis ${ }^{\mathrm{a}, \mathrm{b}}$ & $\begin{array}{c}69 \\
(59-78)\end{array}$ & $\begin{array}{c}25 \\
(15-37)\end{array}$ & $\begin{array}{c}74 \\
(63-84)\end{array}$ & $\begin{array}{c}39 \\
(23-57)\end{array}$ & $\begin{array}{c}58 \\
(49-66)\end{array}$ & $\begin{array}{c}11 \\
(3-25)\end{array}$ & $\begin{array}{c}59 \\
(45-72)\end{array}$ & $\begin{array}{c}10 \\
(1-37)\end{array}$ \\
\hline L. rheocola ${ }^{\mathrm{a}, \mathrm{c}}$ & $\begin{array}{c}58 \\
(46-70)\end{array}$ & $\begin{array}{c}40 \\
(31-51)\end{array}$ & $\begin{array}{c}55 \\
(28-79)\end{array}$ & $\begin{array}{c}33 \\
(15-55)\end{array}$ & $\begin{array}{c}62 \\
(48-74)\end{array}$ & $\begin{array}{c}0 \\
(0-7)\end{array}$ & $\begin{array}{c}63 \\
(31-88)\end{array}$ & $\begin{array}{c}0 \\
(0-26)\end{array}$ \\
\hline L. xanthomera & $\begin{array}{c}0 \\
(0-39)\end{array}$ & - & - & - & $\begin{array}{c}7 \\
(0-28)\end{array}$ & - & - & - \\
\hline Nyctimystes dayi ${ }^{\mathrm{C}}$ & $\begin{array}{c}67 \\
(40-87)\end{array}$ & $\begin{array}{c}74 \\
(59-87)\end{array}$ & - & - & $\begin{array}{c}0 \\
(0-45)\end{array}$ & $\begin{array}{c}3 \\
(1-10)\end{array}$ & - & - \\
\hline
\end{tabular}


group. In addition, we surveyed areas bordering infected bioregions, such as Millstream Falls National Park and Endeavour Valley, or areas more likely to be infected based on favourable climate for $B d$ and species in non-surveyed bioregions, e.g. high altitude rainforest in northeast Queensland, such as the McIlwraith Ranges. Einasleigh Uplands (n = 140 frogs) and Cape York ( $\mathrm{n}=370$ frogs) next to the infected Wet Tropics, and Brigalow Belt South $(\mathrm{n}=65$ frogs $)$ adjacent to the infected South East Queensland

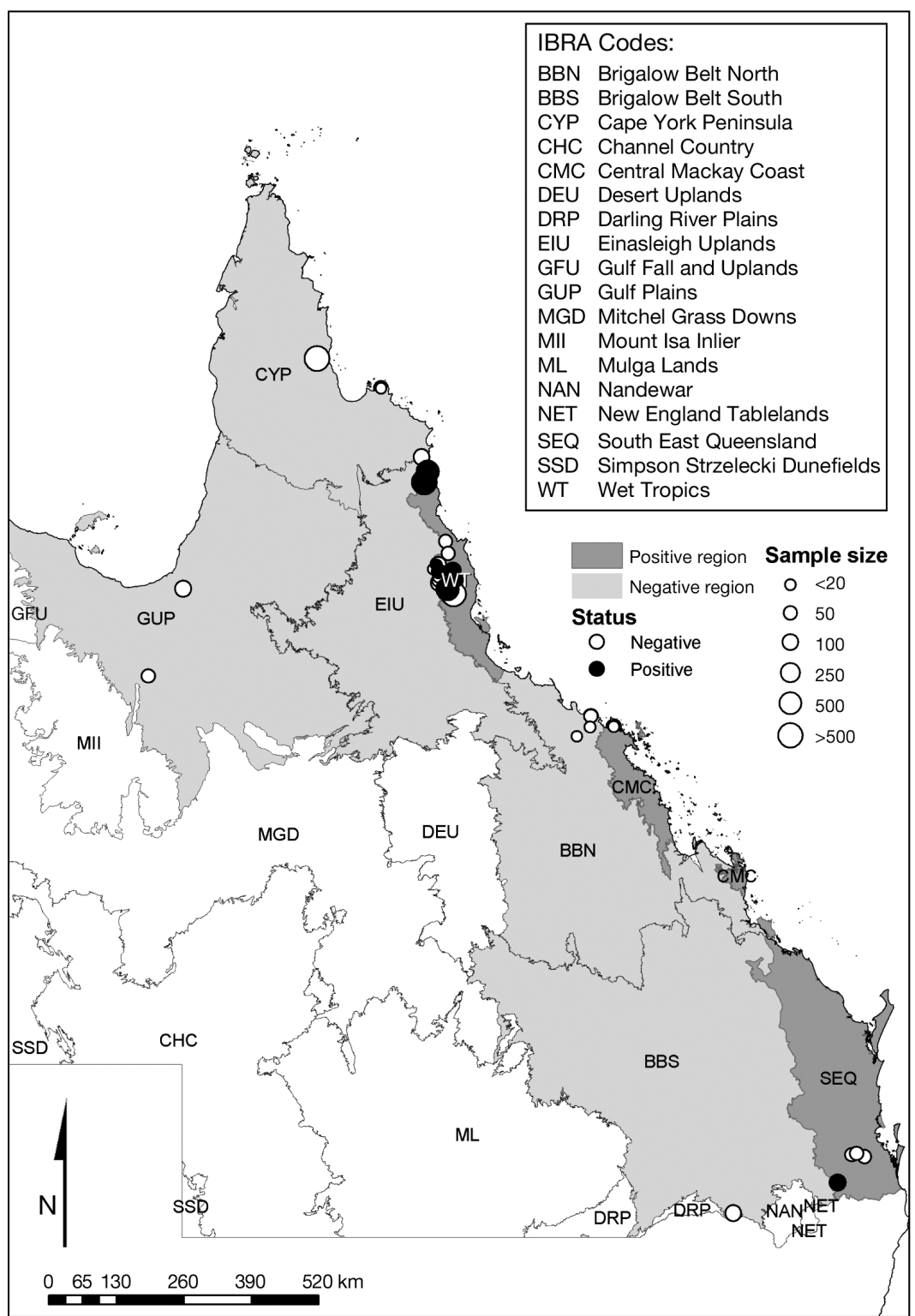

Fig. 1. Batrachochytrium dendrobatidis. Positive ( $)$ and negative $(\mathrm{O})$ bioregions and amphibian populations in Queensland based on surveillance data collected after following the published survey protocol for $B$. dendrobatidis (Skerratt et al. 2008). Size of circles is relative to sample size (Bioregions are based on the interim biogeographic regionalisation of Queensland, Environment Australia 2000). The Central Mackay Coast bioregion was not sampled here but is known to be endemically infected (Berger et al. 2004, Retallick et al. 2004) bioregion were negative (Fig. 1). Previous histological results from surveys of Cape York ( $\mathrm{n}=398$ frogs) and Brigalow Belt North ( $\mathrm{n}=68$ frogs) were also negative.

Groups not surveyed in infected bioregions (1c). The ephemeral water group in Queensland generally remained negative although permanent water group species within $1 \mathrm{~km}$ were positive for $B d$ (Table 1). Forty-one Litoria caerulea from South East Queensland and 121 frogs of several species from the Wet Tropics were negative. The exception were 2 populations of $L$. xanthomera which were positive at $15 \%$ ( $\mathrm{n}=39$ frogs) in the Wet Tropics uplands. Previous histological results support these findings, with only 1 L. infrafrenata positive from 702 frogs of various species tested from the lowlands of the Wet Tropics (Table 1).

Species not surveyed in infected bioregions (1d). Litoria lesueuri in the permanent water group had a prevalence of $18 \%$ ( $\mathrm{n}=39$ frogs). These infected populations were in cool and wet, high altitude locations in rainforest in the Wet Tropics (Table 1).

Bioregions not surveyed and not next to infected bioregions (1e). The permanent water group was not accessible during the monsoon in this bioregion, the Gulf Plains. Therefore, 71 frogs of several species belonging to the ephemeral water group were sampled and all were negative. Combining species to achieve the required sample size was a modification of the original protocol. Previous results using histology from the Gulf Plains ( $\mathrm{n}=34$ frogs) were also negative (Fig. 1).

Tadpoles versus adults (10). Litoria nannotis and L. rheocola tadpoles had consistently higher prevalences compared with adults in both winter and summer at 2 sites in the Wet Tropics. In contrast, adult L. genimaculata had higher prevalences in winter. There was no difference for Nyctimystes dayi (Table 2).

GPS results at survey sites (11). GPS results were collected at all sites and have been given in Table 1 for some sites. Complete data are available from the authors. 


\section{Hygiene}

We also tested our wet shoes $(\mathrm{n}=11)$, hands $(\mathrm{n}=2)$ and stream water at infected sites $(n=6)$ using swabs after sampling frogs and prior to disinfection. All were negative.

\section{DISCUSSION}

Using the survey protocol of Skerratt et al. (2008), $B d$ was detected in all threatened stream-dwelling rainforest species in South East Queensland and the Wet Tropics at all localities except when sample size was $<10$ individuals. This result was expected as all of these species have been positive for $B d$ in the past at these localities (Berger et al. 2004, McDonald et al. 2005).

Chytridiomycosis was not detected in the Gulf Plains in the far west, and in bioregions adjacent to infected ones - Cape York, Einasleigh Uplands, Brigalow Belt South and Brigalow Belt North. The latter bioregion was the least sampled ( $n=68$ ), and the histological testing was conducted prior to development and application of the survey protocol. Therefore, it is not surprising that 2 Litoria caerulea with chytridiomycosis have been found in the Brigalow Belt North bioregion, at Dysart and Biloela (Berger et al. 2004). This bioregion needs further sampling following this survey protocol to determine whether there are pockets of endemic infection or whether infection spills over intermittently from the neighbouring endemically infected Central Mackay Coast bioregion (Berger et al. 2004, Retallick et al. 2004).

Generally, species in the ephemeral water group were not infected even though they occurred in infected bioregions. This is probably because the ephemeral species utilize water bodies which do not become contaminated with $B d$ during their short existence and also because these species often inhabit open forests or habitats which are generally hotter and drier than rainforest in these areas. The exceptions were 2 infected populations of Litoria xanthomera, which is a species that occurs in rainforest and adjacent wet sclerophyll tall open forest and breeds in ephemeral pools within rainforest streams which are known to have $B d$. They also breed in isolated waterholes or road table drains within rainforest or tall open forest. Infection was also detected in tadpoles. The full impact of $B d$ on $L$. xanthomera is unknown and difficult to determine as these frogs are cryptic in winter when conditions are more favourable for chytridiomycosis. Another exception was 1 infected $L$. infrafrenata in a banana plantation adjacent to rainforest. This likely represents recent dispersal as this species may also inhabit margins of rainforest. Terrestrial species are not readily exposed to contaminated water bodies and less likely to be infected.
$B d$ was detected in non-threatened species belonging to the permanent water group in infected bioregions at all well sampled localities except for one, Webster Road. This agrees with previous reports (Berger et al. 2004, Kriger \& Hero 2007a). The bioregion Gulf Plains, which is distant from an infected bioregion, proved negative and confirms the view that these bioregions should not be sampled unless anthropogenic importation is likely, climatic modelling indicates favourable areas for $B d$ and species susceptible to infection are present.

Infected populations in rainforest areas showed increased prevalence at lower temperatures, similar to the results of previous studies in these areas (McDonald et al. 2005, Woodhams \& Alford 2005, Kriger \& Hero 2007b). Mortality from chytridiomycosis also increases at lower temperatures, such as in winter (Berger et al. 2004, Murray et al. 2009). However, abundance of frogs is often decreased at lower temperatures, so there is a trade-off between ease of finding frogs and likelihood of them being infected with $B d$. Similar trade-offs are likely to occur elsewhere in Australia. Regardless, $B d$ is easily detected in these populations with minimal survey effort at any time of the year. Populations elsewhere in Australia with similar high prevalence of $B d$ should also be relatively easy to confirm as positive for $B d$.

Permanent water breeders in mesic habitats in Queensland have been reported with a high prevalence of $B d$ (Retallick et al. 2004, McDonald et al. 2005, Kriger \& Hero 2007a). Our results confirm this and support the survey protocol recommendation that they should be targeted first when surveying new areas. Our results also suggest that $B d$ may not be as important a pathogen in other ecological groups compared with the permanent water group, which is mostly comprised of stream-associated frogs in northern Australia. This concurs with the severe effects that $B d$ appears to have had on the abundance of stream-associated frogs. In southern Australia, these relationships between $B d$ and ecological groups may differ due to lower temperatures and different rainfall patterns.

Although positive records from one of the drier inland bioregions, such as the Gulf Plains, would drastically change the predicted distribution of $B d$ (Retallick 2003), it appears that these regions are likely to be negative for $B d$ and that the current biogeographical model is reasonably accurate (Murray et al. in press a). Extensive sampling in these regions is likely to be unrewarding and it is recommended that bioregions next to infected bioregions that have not been previously surveyed have the highest priority for a Queensland survey.

As the aim of the survey protocol is to map the distribution of $B d$ in all Australian frog populations in a cost- 
effective manner, it is clear from this study that prioritisation is important. This study suggests that $B d$ has higher prevalences in species that have experienced known declines. Drier and/or warmer bioregions next to currently known infected bioregions may not have $B d$ or the fungus may occur only intermittently due to spillover during favourable climatic conditions. Non-permanent water groups are generally not infected in northern Australia. Therefore, when surveying frog populations in northern Australia, it is important to start with permanent water species, which are mostly stream-associated species, especially those that have declined, in mesic environments such as rainforest experiencing moderate temperatures $\left(<27^{\circ} \mathrm{C}\right)$ for at least part of the year.

It appears that the probability of detecting $B d$ declines as the environment becomes more xeric ( $B d$ was confined to rainforest and habitats bordering rainforest such as wet eucalypt forests in Queensland), temperatures increase $(B d$ declined in prevalence in the Wet Tropics during summer) and frog species spend less of their life history associated with permanent water (permanent water group species were consistently infected, explaining why they have undergone the greatest declines, whereas ephemeral water group species were rarely infected). Within these general trends, there may be minor exceptions, such as when drier conditions result in frogs being closer to permanent water and having increased risk of exposure to $B d$. For example, intermittent outbreaks of chytridiomycosis and mortality occur in Litoria caerulea in winter in South East Queensland (Berger et al. 1999a). If $B d$ is absent in a bioregion in frog populations likely to be infected, then it would not be cost-effective to survey sympatric species that have a lower risk of being infected. Similarly, if $B d$ is absent from a bioregion, then it would be inefficient to survey surrounding bioregions that are less likely to be infected. However, more work is needed to confirm that ecological and environmental effects on $B d$ are consistent throughout Australia, especially in the south where climate and habitat differs significantly from Queensland.

When present, chytridiomycosis occurred at apparent prevalences of $\geq 5 \%$ in permanent and ephemeral water-associated species in this survey using swabbing of skin and qPCR as a diagnostic test, even when sampling occurred at times climatically unfavourable for $B d$, such as summer for Mixophyes fleayi in South East Queensland. Therefore, the survey protocol of aiming to detect a minimum apparent prevalence of $5 \%$ is appropriate in susceptible species and areas climatically favourable for $B d$. It is possible that $B d$ occurs at prevalences $<5 \%$ in some frog species occurring in marginal habitats for $B d$. Therefore, we recommend that further work be done to establish that $B d$ as detected by qPCR does not occur at apparent preva- lences $<5 \%$ in some species and environments. This is an issue for amphibian trade in terms of ensuring that animals are sourced from $B d$-free populations and conservation management, as $B d$ will be less of a threatening process in species and areas which are marginal for its survival.

Tadpoles did not have higher prevalences in all cases: compared with adults, tadpole prevalences were higher for 2 species, Litoria nannotis and L. rheocola, lower for 1 species, L. genimaculata, and did not differ for another, Nyctimystes dayi. Hence, the cost effectiveness of sampling tadpoles depends on the species. However, tadpoles can be easier to collect than adults in some environments. When access is time limited, tadpoles can be ideal, if available, as collection is possible during daylight hours. Therefore, the life stage with the higher prevalence for a particular species should be confirmed before undertaking extensive sampling and this, plus access to specimens, will determine which stage is the most cost-effective to sample.

Batch testing lowered the sensitivity of the qPCR when only 1 swab of the 5 in the batch was positive at a very low intensity of infection in Mixophyes fleayi. It is also likely that samples from this species had a high level of inhibition of the qPCR. Approximately $70 \%$ of samples from this species had inhibition based on subsequent testing with an internal positive control, which would have contributed to the low levels of $B d$ detected by the qPCR (Hines 2007). This result is similar to the experimental results of Hyatt et al. (2007) where an individual swab spiked with a low number of zoospores was not detected in a batch of 5. One could concentrate samples to overcome the dilution effect of batching.

Given that the survey protocol has been applied successfully in Australia, with some minor modifications listed below, it may be useful for mapping the distribution of $B d$ globally. We generally found the protocol feasible and sufficiently flexible. Results derived from the survey protocol agreed with previously collected opportunistically collected data reported here and previously (Berger et al. 2004). Environmental conditions at the time of collection, particularly local rainfall in the monsoonal areas, greatly affected detection of species and abundance. As included in the protocol, surveyors need to be prepared to collect species that are readily detectable and in sufficient numbers while in the field rather than just targeted species, especially for non-stream breeders in more xeric habitats. Sometimes, one must combine samples from several species from an ecological group to achieve the desired sample size and may need to collect up to 20 individuals from a collection point. These are slight modifications to the original protocol. Surveys must also be prepared to sample larvae depending on availability, but taking note that in some species, prevalences of $B d$ in tadpoles may be lower than in adults. 
The frog populations which are a priority for wildlife managers are negative populations which are at risk of introduction of $B d$ and potential epidemics of chytridiomycosis. In Queensland, these are the permanent water-associated species Litoria eucnemis and $L$. longirostris in rainforest that experiences moderate to high temperatures and monsoonal rainfall on the Mcllwraith Ranges in mid Cape York. Currently, the risk appears to be low due to the inaccessibility of the area preventing anthropogenic spread, the isolation of the area $(300 \mathrm{~km}$ distant $)$ from infected areas in the Wet Tropics and the likelihood that climate may be unfavourable for $B d$ in late spring and early summer when it is hot and dry. It is likely that the impact of the disease on $L$. eucnemis and L. longirostris in the McIlwraith Ranges will be less compared with cooler rainforest areas at higher altitude and further south in the Wet Tropics where populations of similar species have declined, some have been extirpated and at least 1 species, Taudactylus acutirostris, has become extinct due to chytridiomycosis (Australian Government Department of the Environment and Heritage 2006a, Schloegel et al. 2006). These populations should be monitored and an emergency response plan followed if $B d$ is introduced. Currently, an emergency response plan does not exist and is a priority for amphibian conservation globally. In addition, our results suggest that species may be conserved by protecting them in environments where $B d$ does not currently occur, such as on Cape York. Species already extirpated from a large proportion of their distribution by $B d$ may be conserved by protecting them in environments that are suboptimal for $B d$, as in hotter lowland rainforest compared with higher altitudes. This has occurred with Litoria nannotis, L. rheocola, Nyctimystes dayi and Taudactylus eungellensis. In addition, more xeric environments, like eucalypt forest compared with rainforest, are protective (Puschendorf 2009). We recommend surveys of the distribution of species threatened by $B d$ to identify populations in areas suboptimal for $B d$ for conservation protection. This may also lead to the rediscovery of species thought to be extinct. Lastly, our data suggest that $B d$ has almost reached the limits of its distribution in Queensland, being confined to the 3 wetter and cooler bioregions of the state, South East Queensland, Central Mackay Coast and the Wet Tropics. Higher resolution mapping and modelling is needed to identify the exact limits of the distribution of $B d$ in Australia (Murray et al. in press a). This will detect populations that may be most affected by chytridiomycosis as well as naïve populations at risk of introduction of $B d$ (Murray et al. in press b). It will also inform management decisions, such as which populations need ongoing monitoring, quarantine, emergency response plans, captive breeding programs, translocation and reintroduction of frogs, and treatment with fungicides. However, given the stable distribution of $B d$ in Queensland, the priority for management is reducing its impact in affected populations by assisting selection for immunity and dispersal through captive breeding and reintroduction and translocation efforts. Research is also needed to improve these management options, which have had varied success due to a lack of understanding of the epidemiology of chytridiomycosis.

Acknowledgements. This study was funded and initiated by the Australian Government Department of Environment and Heritage (tenders 63/2003 and 42/2004), and also funded by the Australian Research Council and a research career development grant to L.F.S. from James Cook University. We thank R. Campbell for conducting qPCR analyses, and S. Young, A. Robbins and P. Baxter for helping to design and interpret the results from the targeted survey strategy.

\section{LITERATURE CITED}

Aplin K, Kirkpatrick P (2000) Chytridiomycosis in southwest Australia: historical sampling documents the date of introduction, rates of spread and seasonal epidemiology, and sheds new light on chytrid ecology. Proc Getting the Jump on Amphibian Disease, Cairns, Australia, 26-29 August 2000, p 24. Available from: www.jcu.edu.au/school/phtm/ PHTM/frogs/GJAplin.htm (Accessed Feb 2009)

Australian Government Department of the Environment and Heritage (2006a) Threat abatement plan: infection of amphibians with chytrid fungus resulting in chytridiomycosis. Department of Environment and Heritage, Canberra. Available from: www.environment.gov.au/ biodiversity/threatened/publications/tap/pubs/chytridreport.pdf (Accessed Feb 2009)

Australian Government Department of the Environment and Heritage (2006b) Background document for the threat abatement plan: infection of amphibians with chytrid fungus resulting in chytridiomycosis. Department of Environment and Heritage, Canberra. Available from: www. environment.gov.au/biodiversity/threatened/ publications/tap/pubs/chytrid-background.pdf (Accessed Feb 2009)

Australian Government Department of the Environment and Water Resources (2007) IBRA Version 6.1. Available from: www.environment.gov.au/parks/nrs/science/bioregionframework/ibra/index.html\#ibra (Accessed Feb 2009)

Australian Government Department of the Environment, Water, Heritage and the Arts (2009) EPBC Act list of threatened fauna. Available from: www.environment.gov. $\mathrm{au} / \mathrm{cgi}$-bin/sprat/public/publicthreatenedlist.pl?wanted= fauna\#FROGS_EXTINCT (Accessed Feb 2009)

Berger L (2001) Diseases in Australian frogs. PhD thesis, James Cook University, Townsville

Berger L, Speare R, Hyatt A (1999a) Chytrid fungi and amphibian declines: overview, implications and future directions. In: Campbell A (ed) Declines and disappearances of Australian frogs. Environment Australia, Canberra, p 23-33 
Berger L, Speare R, Kent A (1999b) Diagnosis of chytridiomycosis of amphibians by histological examination. Zoos Print J 15:184-190

Berger L, Hyatt AD, Olsen V, Hengstberger SG and others (2002) Production of polyclonal antibodies to Batrachochytrium dendrobatidis and their use in an immunoperoxidase test for chytridiomycosis in amphibians. Dis Aquat Org 48:213-220

Berger L, Speare R, Hines H, Marantelli G and others (2004) Effect of season and temperature on mortality in amphibians due to chytridiomycosis. Aust Vet J 82:434-439

Berger L, Longcore JE, Speare R, Hyatt AD, Skerratt LF (2009) Fungal diseases of amphibians. In: Heatwole $H$, Wilkinson JW (eds) Amphibian biology, Vol 8: Amphibian decline-disease, parasites, maladies and pollution. Surrey Beatty \& Sons, Chipping Norton, p 2986-3052

Boyle DG, Boyle DB, Olsen V, Morgan JAT, Hyatt AD (2004) Rapid quantitative detection of chytridiomycosis (Batrachochytrium dendrobatidis) in amphibian samples using real-time Taqman PCR assay. Dis Aquat Org 60:141-148

Branscum AJ, Johnson WO, Gardner IA (2006) Sample size calculations for disease freedom and prevalence estimation surveys. Stat Med 25:2658-2674

Cogger HG (2000) Reptiles and amphibians of Australia. Reed New Holland, Sydney

Environment Australia (2000) Revision of the interim biogeographic regionalisation of Australia and development of Version 5.1 - Summary report. Environment Australia, Canberra

Hines H (2007) Implementing priority actions for the recovery and management of nationally threatened species and ecological communities - Queensland. Project 9. Prevalence of amphibian chytrid fungus within wild populations of three endangered frog species in southern Queensland. Final Report. Queensland Parks and Wildlife Service, Bellbowrie

Hyatt AD, Boyle DG, Olsen V, Boyle DB and others (2007) Diagnostic assays and sampling protocols for the detection of Batrachochytrium dendrobatidis. Dis Aquat Org 73: 175-192

> Johnson ML, Berger L, Philips L, Speare R (2003) Fungicidal effects of chemical disinfectants, UV light, desiccation and heat on the amphibian chytrid, Batrachochytrium dendrobatidis. Dis Aquat Org 57:255-260

Joly DO, Samuel MD, Langenberg JA, Rolley RE, Keane DP (2009) Surveillance to detect chronic wasting disease in white-tailed deer in Wisconsin. J Wildl Dis 45:989-997

Kriger KM, Hero JM (2007a) The chytrid fungus Batrachochytrium dendrobatidis is non-randomly distributed across amphibian breeding habitats. Divers Distrib 13: 781-788

Kriger KM, Hero JM (2007b) Large scale seasonal variation in the prevalence and severity of chytridiomycosis. J Zool 271:352-359

Kriger KM, Pereoglou F, Hero JM (2007) Latitudinal variation in the prevalence and intensity of chytrid (Batrachochytrium dendrobatidis) infection in eastern Australia. Conserv Biol 21:1280-1290

McDonald KR, Méndez D, Müller R, Freeman AB, Speare R (2005) Decline in the prevalence of chytridiomycosis in upland frog populations in North Queensland, Australia. Pac Conserv Biol 11:114-120

Murray KA, Skerratt LF, Speare R, McCallum H (2009) Detecting the impact and dynamics of disease in species threatened by the amphibian chytrid fungus, Batrachochytrium dendrobatidis. Conserv Biol 23:1242-1252

Murray K, Retallick RWR, McDonald KR, Mendez D and others (2010) The distribution and host range of the pandemic disease chytridiomycosis in Australia spanning surveys from 1956 to 2007. Ecology 91:1557-1558
Murray KA, Retallick RWR, Puschendorf R, Skerratt LF and others (in press a) Assessing spatial patterns of disease risk to biodiversity: implications for the management of the amphibian pathogen, Batrachochytrium dendrobatidis. J Appl Ecol

Murray K, Rosauer D, McCallum H, Skerratt LF (in press b) Integrating species traits with extrinsic threats: closing the gap between predicting and preventing species declines. Proc R Soc B

Obendorf D (2005) Application of field and diagnostic methods for chytridiomycosis in Tasmanian frogs. Central North Field Naturalists, Tasmania. Available from: www. environment.gov.au/biodiversity/invasive/publications/ pubs/tasmanian-frogs.pdf (Accessed Feb 2009)

Obendorf D, Dalton A (2006) A survey for the presence of the amphibian chytrid fungus (Batrachochytrium dendrobatidis) in Tasmania. Pap Proc R Soc Tasman 140:25-29

Phillott AD, Speare R, Hines HB, Meyer E and others (2010) Minimising exposure of amphibians to pathogens during field studies. Dis Aquat Org 92:175-185

Puschendorf R (2009) Environmental effects on a hostpathogen system: frogs and Batrachochytrium dendrobatidis in wet and dry habitats. PhD thesis, James Cook University, Townsville

Retallick RWR (2003) Bioclimatic investigations into the potential distribution of Batrachochytrium dendrobatidis in Australia, draft report. University of Queensland, Brisbane

Retallick RWR, McCallum H, Speare R (2004) Endemic infection of the amphibian chytrid fungus in a frog community post-decline. PLoS Biol 2:e351

Schloegel LM, Hero JM, Berger L, Speare R, McDonald K, Daszak P (2006) The decline of the sharp-snouted day frog (Taudactylus acutirostris): the first documented case of extinction by infection in a free-ranging wildlife species? EcoHealth 3:35-40

Skerratt LF, Berger L, Speare R, Cashins S and others (2007) The spread of chytridiomycosis has caused the rapid global decline and extinction of frogs. EcoHealth 4:125-134

Skerratt LF, Berger L, Hines HB, McDonald KR, Mendez D, Speare R (2008) Survey protocol for detecting chytridiomycosis in all Australian frog populations. Dis Aquat Org 80:85-94

Speare R, Berger L (2007) Global distribution of chytridiomycosis in amphibians. Amphibian disease home page. James Cook University, Townsville. Available from www.jcu.edu.au/school/phtm/PHTM/frogs/chyglob.htm (Accessed Feb 2009)

Speare R, Berger L, Skerratt LF, Alford R and others (2004) Hygiene protocol for handling amphibians in field studies. James Cook University, Townsville, Australia. Available from: www.jcu.edu.au/school/phtm/PHTM/frogs/fieldhygiene.pdf (Accessed Feb 2009)

Speare R, Skerratt LF, Berger L, Hines H, and others (2005) A project that designs and trials a pilot survey to map the distribution of chytridiomycosis (caused by the amphibian chytrid) in Australian frogs. Final report for Project ID 44381 (tender 63/2003) to the Australian Government Department of Environment and Heritage. Australian Government Department of Environment and Heritage, Canberra. Available from: www.deh.gov.au/biodiversity/ invasive/publications/c-disease/distribution-survey.html (Accessed Feb 2009)

Tyler MJ (1994) Australian frogs. A natural history. Reed Books, Chatswood

- Woodhams DC, Alford RA (2005) Ecology of chytridiomycosis in rainforest stream frog assemblages of tropical Queensland. Conserv Biol 19:1449-1459 